\begin{tabular}{c} 
Volume and Issues Obtainable at Center for Sustainability Research and Consultancy \\
Journal of Business and Social Review in Emerging Economies \\
ISSN: 2519-089X (E): 2519-0326 \\
Volume 6: No. 3, 2020 \\
¿SRᄃ \\
Journal homepage: www.publishing.globalcsrc.org/jbsee \\
\hline
\end{tabular}

\title{
Sino-Iranian Strategic Partnership: Prospects and Challenges
}

\author{
${ }^{1}$ Sehar Sabir, ${ }^{2}$ Muhammad Ijaz Latif \\ ${ }^{1}$ Assistant Professor, Department of International Relations, The Islamia University of Bahawalpur, Pakistan \\ Sehar.sabir@yahoo.com \\ ${ }^{2}$ Professor and Chairman Department of International Relations, The Islamia University of Bahawalpur, Pakistan \\ Ijaz.latif@iub.edu.pk
}

\begin{tabular}{l} 
ARTICLE DETAILS \\
\hline History \\
Revised format: August 2020 \\
Available Online: September \\
2020
\end{tabular}

\section{Keywords}

China, Energy, Iran, Middle East, Strategic Partnership.

\section{JEL Classification}

M40, M48

\begin{abstract}
China and Iran have developed mutual inter-dependence and bilateral cooperation in several fields. Though China and Iran are closer to sign 25 year strategic partnership, yet the final draft of the deal is being negotiated between the two parties. The expectations are high on Iranian side, however one or anotherway there are multiple factors associated with such developments. For instance; Chinese image in contemporary international system, US factor, international sanctions against Iran, Iranian perception and role in the region, and Chinese ambitious Belt and Road initiative is supposed to determine the depth and sustainability of this strategic partnership. This paper argues that the apprehensions attached to the deal are reflecting western perception whereas China's interest are more economic/commercial and business oriented, thus limiting their cooperation in other fields. This paper addresses the prospects of these negotiations considering the impact of afore mentioned factors on the background of their relations, thus articulates challenges faced by both the parties for expected enhanced strategic partnership. The paper concludes that SinoIranian cooperation is not only confined to economic field rather expands to socio-cultural and technological fields as well, but this must also be viewed as part of China's over all Middle East policy considering her economic might and investment posture through Belt and Road initiative.
\end{abstract}

(C) 2020 Center for Sustainability Research and Consultancy Pakistan under a Creative Commons Attribution-NonCommercial-ShareAlike 4.0

Corresponding author's email address: Ijaz.latif@iub.edu.pk

Recommended citation: Sabir, S., \& Latif, M. I. (2020). Sino-Iranian Strategic Partnership: Prospects and Challenges. Journal of Business and Social Review in Emerging Economies, 6(3), 1043-1050

\section{Introduction}

China-Iran relations have entered a phase of strategic partnership with Chinese Presidents Xi-Jinping's 2016 visit to Iran that recorded signing of several agreements and many commitments to expand cooperation beyond traditional diplomatic and economic ties. At present both are negotiating to draft a plan for 25years strategic partnership, as it took 4 years to finalize, the plan might contain roadmap for the coming years. The precursor to this agreement met mix response from the analytic community however a lot more needs to be done by the epistemic community. Although it has been viewed from the geopolitical lens by majority of analysts yet the economic/commercial dimension is greatly missed. China's approach towards the conflict ridden/internationally isolated, economically deteriorating and fragile states is undoubtedly founded on the "peace through economic development" framework. One must keep in mind the economic side of Chinese interests in the region while analyzing Chinese foreign policy 
moves. For this reason the economic interests might serve other interests as well in junction with the primary commercial advantages. This gives China an upper hand in monopolizing these areas where the west is at par with reaping these benefits. As the world politics is based on the "might is right" principle so the growing Chinese footprints are the results of its rising economic status and is in sharp contrast with that of the relative declining status of the US.

\section{Research Question}

This paper seeks investigates Iran's placement in China's Middle East policy? Is it China's Forward policy for countering US in the Middle East or the relationship is only economic/commercial/business interest oriented?

\section{Argument}

The paper argues that, although the deal is purely economic in nature yet it includes components of military cooperation, arms sales and other strategic nature of partnership. It is arguably conceived in an environment of SinoUS deteriorating mutual interdependence and disagreements on several issues encompassing trade, politics, geopolitics and several other areas. In this scenario the deal is viewed as aimed against US interest, yet this paper argues that the agreement can be viewed from commercial/economic/business lens as well. One must notice Chinese behavior towards the region, her immediate concerns, and long-lasting impacts. China's excessive use of her economic statecraft makes her a more reliable and quickly accessible partner to the states in need. Chinese policy of providing aid and assistance with no pearls attached is the mammoth of her Belt and Road Initiative as well. China has been using her economy both as tool of persuasion as well as a tool of coercive diplomacy. Hence signing of this strategic deal is a business as usual on Chinese behalf, however the incentives attached to this deal makes Chinese ambitions suspicious as an anti-US strategy. China is rather adopting more traditional policy to have more and more like-minded states in Asia and Africa. Iran is more an economically potential, and culturally influenctial partner through Central Asia to address the intimidating threat of separatism in China's western province.

\section{Iran-China Relations: Historical Background}

Historically the chronicle of China-Iran relations have been swamped with responsiveness and amicability, as China maintained trade ties with ancient Persia via Silk Road since ages. It is also considered that the Silk Route was the outcome of their splendid diplomatic relations (Hameed, 2010:136-137). Though diplomatic relations were not strong yet trade relations, Budhist monks' missionary works and military contacts developed mutual exchanges (Hameed, 2010:136-137). The visits by the Chinese imperial fleets to Persia during Ming Dynasty (especially with regard to trade expansion to outside world and cultural tieswith the west) indicate the maritime dimension of this linkage (Levathes, 1994). However Middle east became less as an area of inerest with China giving up maritime presence and the decline of Silk Road trade.

As the communist forces under the leadership of Mao-Zedong declared independence the relationship became complicated. The cold war scenario determined the dimensions of Sino-Iranian relations, initially China was engaged in friendly relations with the communist bloc led by Union of Soviet Socialist Republics (USSR) whereas Iran sided with the capitalist bloc led by the United States; resulting in divergence of interest hence both did not develop direct diplomatic ties. In 1951, China provided political and ideological support to the socialist forces in Iran and openly criticized the growing interference of the United States in the affairs of Iran in the wake of Iranian efforts to nationalize British oil companies by nationalist leader Mohammed Mossadiq (Hameed, 2010:136).

During Cold War, China used some of her funds to support the communist parties in the Arab World though shortly, but later due to China's domestic circumstances she reduced her interests in the region (Mackenzie, 2010:1). Chinese concerns of Iranian's decision to join Baghdad pact in 1955, and establishing official ties with Taiwan, cemented latter's integration into the western block and kept the former at par with coming closer. In the early 1960s, Beijing sheltered a faction of the Iranian communist Tudeh Party in Beijing and also started import of crude Iranian oil though modest quantities (Calabrese, 2016:2).

In aftermath of Sino- Soviet rift during 1960s China neither supported socialist groups nor Phelavi regime as the former was seeking patronage from the Soviet; a newly surfacing confronting partener for China and latter was closer 
to the United States. In the coming years Chinese Cultural Revolution's after effects, emergence of young pro-China intellectuals and political activists within Iran (Emadi, 1997:35-39), and improvement in Sino-US image of each other also improved China's relations with the Iranian Shah's regime. A conviction is made about Shah's decision to launch full-scale diplomatic relations with China, after getting positive signal from the US (Emadi, 1997:35-39) as Shah extended recognition to Beijing as the sole legal government of China (Daftari, 1996: 865-76) and proclaimed diplomatic ties with China on August 17, 1971 two days after Mao-Nixon Summit (Emadi, 1997:35-39).

In coming years, both shared common concern for Soviet expansion in the entire region and cooperated over supporting anti-communist vigor/parties in Indo-Pakistan (1971) war, Soviet-supported rebellion in Southern province of Oman, Soviet/Cuban moves in the Horn of Africa and supported Egypt's shifting away from the Soviet Union under Sadat's regime (Garver, 2016:181). The relations turned reverse with the Islamic revolution in Iran in 1979. China having history of revolutions and anti-west orientation was viewed as revolutionary power in and thus supporting revolutions. However China opted to stand with the anti-revolutionary and status quo forces in the region. As the progress made for economic and cultural exchanges was reversed by the Iranian revolution (Hameed, 2010: 137).

Chinese and Iranian ways diverged in a manner that despite China's encouragement and recognition of revolutionary regime under her principle of peaceful coexistence, but the Iranian response could not match China's pace; rather Iran maintained non-alignment and critised China's policies in the past. China though reluctant to proactively engage with Iran, considered Iranian response, her own priority of moderating relations with the US and a concern that tilting more towards Iran may derail the process of normalization of relations with the US, hence China criticized Iranian action, withdrew and termed the taking hostages of American diplomats as violation of International Law (Emadi, 1997:4243, and Calabrese, 2006: 7).

Once again economic consideration rearranged their mutual partnership with the initiation of Iran-Iraq War in 1980. "While the United States and USSR supported Iraq, Chinese policymakers, pursuing modernization and market reform under Deng Xiaoping, were attracted by the economic benefits to be reaped by selling arms to Iran" (Hameed, 2010:137) These factors and consideration compelled China to revisit its foreign policy towards Iran. By the last years of the Iran-Iraq war, China had emerged as Tehran's major supporter in United Nations (UN) Security Council actions to end that war (Garver, 2016:182).

Similarly Iran also considered reassessing its policy towards China due to the factors including economic burden of war with Iraq, war and democracy related economic sanctions, emergence of pragmatists determined to defy the US agenda of isolating Iran to power, and the urgent need for reconstruction, rehabilitation, arms and ammunition (Emadi, 1997:42-46). The war left Iran with the realization that the global political dynamics and scenario has changed thus the pre-requisites for the Iranian policy towards major powers must also be revisited, this realization resulted in significant progress of mutual relations between the two until the Soviet disintegration.

In the first half of the 1990s decade both observed convergence of mutual dependencies as Iran faced pressing economic reconstruction needs, compounded by an acute foreign exchange crisis and a severe deficiency in the level of domestic investment (Calabrese, 2016:4) and looked towards East Asia (Emadi, 1997:45) preferably over the West. Whereas China expanded oil needs for her fast-growing economy becoming one of the World's largest oil importers, hence Iran along with Central Asia could become one of the major options to fulfill this need. During 1990s Iran became net exporter for China's oil supply and it became China's top foreign policy priority to develop pipelines or rail and road links to secure energy resources and supplies (Downs, 2006). Iran since long ago was a more attractive, appropriate and more feasible option for China's oil needs.

The second half of 1990s decade was influenced by the US factor, as the Sino-US tensions grew in the wake of third Taiwan Strait Crisis of 1995-1996, China warmly hailed to Iranian approach of rapid market expansion. The US strict policies to isolate Iran helped bringing Iran closer to China, as both continued to develop mutual cooperation in many fields. The nuclear issue, and US launching of War against terrorism added another dimension to their relations. As with the 9/11 attacks on US soil, it adopted hard stance over Iran, declaring Iran as "axis of evil" and accusing her of 
acquisition of WMDs, sponsoring terrorism, infiltration in Afghanistan, supporting terrorist organizations, and violations of human rights. This not only mounted pressure on Iran, rather it was an indication for the states cooperating with her as well, creating uncertain and susceptible situation for China's diplomatic, economic, political and military cooperation with Iran.

Defense cooperation between Iran and China is complicated due to Iran's expectations and China's reluctance. However the oil factor remains detriment of cooperation beyond economic commercial and business terms. Iran is in dire need of partner in trade for defense equipment although reluctant though limited provision of Chinese military equipment supplies to Iran deteriorates Chinese image in international arena. China being moving towards normalization of relations with the US, the former kept defense cooperation with Iran negligible, however Iran-Iraq war changed dimension of the Chinese cooperation with Iran. Though Iran imported arms and ammunition worth $\$ 600$ million in 1986(Emadi, 1997:45) but these transaction were not direct between the parties rather discretely though third-party sale.

Iran is also considered to modernize her military with indirect but crucial Chinese cooperation. (Harold \& Nader, 2012:7). The list of defense cooperation between Iran and China is enormous as per western sources, including HY-2 (Silk Worm) (Kemenade, 2009:44) anti- ship cruise missiles, short range M-7/8610 ballistic missiles, and technology for the indigenous production of Iran-130 ballistic missiles, anti-ship and ballistic missiles (Garver, 2007:13-17) whereas Chinese official denial from such arms sale and assistance makes room for other explanations as well. China officially remained adhere to Missile Technology Control Regime guidelines. Though these official stances could not satisfy US and alleged China of providing both material and diplomatic support to the Iranian nuclear program.

\section{Sino-Iranian Strategic Partnership and the Western Apprehensions}

Apparently the strategic partnership between Tehran and Beijing dates back to the Chinese President Xi Jinping's visit to Iran in January 2016, the joint statement consisting of 20 article identified areas of collaboration; Political, Executive Cooperation, Human and Cultural, Judiciary, Security and Defence, and Regional and International domains (Joint Statement on Comprehensive Strategic Partnership, 2016). The roadmap prepared for the strategic cooperation was hoped to be cemented with the signing of deals in the coming year by then. The recent wave of dialogues and exchange visits by the designated officials is for the follow-ups and negotiations to draft the deal. The proceedings of one such dialogue has been made public by the western news media which not only have complicated the situation for both the parties but have also raised concerns of the regional and global stakeholders as the deal was hyped to increase Chinese access and influence in the region even at the expense of other stakeholders.

As pointed out by Tom Hussain (2020) this responsible stakeholder behind creating hype about the deal is US media. The New York Times published the leaked draft of the proposed Sino-Iranian agreement claiming it to cost around US\$400 billion, and to include Chinese presence in banking, telecommunication, ports, and several other projects including military cooperation, joint training and exercises, joint research, weapon development and intelligence sharing to counter evils of terrorism, cross-border crimes, drug and human trafficking (Fassihi \& Myers, 2020). The author opined that this deal is going to present a severe blow to the US' anti-nuclear acquisition sanctions policy against Iran. Now the apprehension raising from the analysis is whether the cause of concern for US is the negative impact on its sanctions policy or to shift the burden of failure of this policy over Chinese support to Iranian oil export economy? The fact being that the US signed P5+1 Joint Comprehensive Plan of Action over Iranian nuclear issue in 2015 and the trump administration withdrew unilaterally, whereas other partners of the deal are of the view that Iran is complying with the demands of the deal.

The ambiguous response from the Chinese spokesman, Zhao Lijian added more to the US suspicions (Fassihi \& Myers, 2020). The news report cited the Jask port facility supposed to provide China strategic edge over the Strait of Hormuz located near Persian Gulf from where much of the world's oil transit passes through. The Lowy institute accepts this apprehension and validity of the leaked document in an opinion authored by Jeffrey Payne (2020), who rightly pointed towards the regional impacts and concerns of the regional players over the issue, however in a short piece of writing the author made predictions about the future of inexperienced China's entanglement in regional geopolitics. Opposed to the calculations made by the pundits, the Sino-Iranian trade curve is declining since Trump's 
sanctions as China's export to Iran declined since 2018. During the 2019 Iran exported to China goods worth $\$ 15$ billion and imported goods worth \& 10 billion (Guller, September 4, 2020) in 2017 this trade volume was around $\$ 50$ billion.

A major number of scholars account for oil as a determining factor in China-Iran relations, however their partnership is not limited to the oil-based fact only. As Garver (2016) have rightly considered it an unfortunate tendency and mentioned that the mutual interest of both China and Iran is to reconcile in post-US unipolar world. A major criticism of the deal encompasses Chinese access to the Iranian oil despite US sanctions. However the fact remains that the Chinese import of Iranian oil is decreasing since the Trump administration imposed sanctions in 2018. Since reimposition of US sanctions China's supposed purchase of 700,000 barrels of Iranian crude oil per day has only been limited to 90,000 barrels per day (Guller, September 4, 2020). Continuing this pace the Chinese trade with Iran further declined after the US issued executive order 13902 (January 10, 2020), currently China imported only 82,000 barrels per day (Jalilov, May 1, 2020) during the first quarter of 2020. The import from Iran in China recorded the lowest in May 2020 since 2014 (Trading Economics). The executive order impacted China-Iran oil trade severly on the one hand it decreased China's oil export from Iran nine times lower than before execurtive order was issued, on the other hand increased US oil export to China, as China's oil imports from the U.S. almost doubled in July, the average daily U.S. oil shipments to China from Janurary to July also show a growth of 31\% (Khatinoglu, August 27, 2020).

Although China remains the largest Iranian Oil importer yet her trade has been negatively impacted by the US imposed sanctions against Iran. Hence the US apprehension of this deal giving China access to Iranian oil for 25 years is constrained by her own sanctions policy, it is considered that the US may toughen her sanctions policy in order to prevent Chinese import of Iranian oil which on one hand can curtail Chinese economic growth although on a lower level on the other hand this will increase Sino-US rivalry as China will be ready to address any factor curbing her energy supply in order to sustain her industrial based economy.

The deal may give rise to Iranian expectation of playing mediatory role and to advance Iranian interests in the Middle East region, however Chinese interest in the region are increasingly at par with those of Iran. China has major trading partners in the region including Saudi Arabia and Isreal, which are ideologically opposed to the Iranian power in the region. Another factor that might curtail their possible cooperation is China's principle of non-interference/nonintervention in domestic affairs of a state. This deal has met domestic criticism from the Parliamentarians accusing Iranian govt. to accept Chinese monopoly over Iranian natural resources for the next quarter of the Century. However the cooperation is not only limited to energy sectors rather it goes way beyond and extends to other sectors as well.

On the other hand analysts also considered this as entirely Iranian-made wish list presented to the Chinese (Horrison \& Vatanka, September 19, 2020). The piece argues about the two possible scenarios one encompassing China having more access in the Middle East Region at the expense of the US and Russian and Iran giving up any hope on the west and turning to the East, and the other that the partnership might be more tactical than strategic and restricted to the economic sphere only (Horrison \& Vatanka, September 19, 2020). In the first case the growing military to military ties, arms sale e.g. anti-ship missiles and sophisticated surveillance capabilities can threaten US naval supremacy in the Persian Gulf. The US perceived this threat even in 1992 and the suspected supplier was Moscow, but contemporarily Trump used this for withdrawing from JCOPA nuclear deal and the threat perceived in the US might prove to be a reason for Trump to win another term as US president.

China Iran relations must also be viewed as part of China's Middle East policy. Although the interests are only limited to the energy sectors yet in the 21st century Beijing perceives Middle East in more expansive terms, however China adopted "minimalist approach" (Scobell, 2018:15) and remained reluctant about robust diplomatic and military involvement. Although Chinese security-wise profile has been raised in Middle East yet it is more symbolic (Scobell, 2018:17). China played role of active mediator for concluding P5+1 nuclear deal and sided with the US efforts to impose nuclear sanctions against Iran under the UNSC resolutions, the Chinese efforts although a result of both internal and external factors contributed to convince Iran for concluding a deal (Garver, 2018:123-148). 


\section{Economic and Trade Relations}

Economic statecraft has been one of the major tools for Chinese foreign policy, and it's been recognized by the partner states that China prioritizes trade and economic relations over political and security/military interference. Similarly China expanded trade ties with Iran soon after they established diplomatic ties. Conversely, trade cooperation areas remained confined to a limited number of products. Though the Iranian revolution and Iran-Iraq war impacted the intensity of trade cooperation at most yet with betterment in the domestic environment in Iran the trade cooperation revived and grew swiftly. One must also consider the factor of Chinese aim of rapid development and enhanced access to oil-rich region, and Iran's desire to reconstruct her war-ravaged economic infrastructure. Growing trade inter-dependence and convergence of needs led both the states to enhance cooperation areas to health sector, oil refineries, infrastructure building, mining, power generation, textile, vehicle manufacturing, and assistance in scientific and technical areas, China also pledged to import few non-oil Iranian commodities and imported non-oil commodities in the coming years as well.

In the wake of 9/11 and deteriorating Iranian image under US label of "axis of evil" though trade graph declined yet the coming years witnessed a major boom in Sino-Iranian trade cooperation. Both the states desired to enhance trade relations and established close ties. The trade was expected to grow by $20 \%$ by 2007 and reached its peak of $\$ 36.5$ billion (including China's trading good to Iran through UAE) by 2008 (Hounshell, 2010) after China and Iran signed several MOUs for solidifying economic cooperation in 2008.Trade and economic cooperation further boosted after establishing permanent Iranian trade center in Shanghai in 2009. Increasing Chinese companies started operating in Iran and resulting in China becoming one of top-three trade partners of Iran in 2010. This further enhanced presence of Chinese companies in Iran in different sectors. Lifting of Iranian nuclear sanction and signing of Joint Comprehensive Plan of Action (JCPOA) further enhanced bilateral trade. However the data shows a decline in bilateral trade as US reemployed sanctions and withdrew from JCPOA in 2018. China's growing interest on Iranian soil must also be viewed in light of Chinese 21st Century project of Belt and Road Initiative (BRI). Though lesser prominent yet more significant component of BRI is high-speed railway from Xinjiang to Tehran, has been materialized and in 2016 exchange of containers through Vessel and freight train has been actualized. China's trade increased up to $\$ 50$ billion (Financial Tribune, $2015 \&$ 2017) in the aftermath of JCOPA and started delining since 2018 from $\$ 42$ billion to $\$ 23.02$ in 2019(Yacoubian, 2019).

Another factor impacting China-Iran relations is the non-interference principle of Chinese foreign policy. A great amount of literature takes into account this factor hindering Chinese unconditional involvement in the region. Some authors considered Afghanistan as a test case for the conflict between Chinese aspiration of being a major player in the region and the limits of non-interference principle, others considered Iran as the test case for growing Chinese presence amid the talks over this strategic partnership. The principle of Chinese non-interference/non-intervention is long debated among the policy makers, experts and academicians as few attribute Chinese preference to "keeping low profile" in international affairs others seek Chinese "pro-active engagement" both adhere to Deng Xioping's famous saying "hide your capabilities, bide your time". The only difference is over the timing for China to show to the world her capabilities and rise as a major power.

China-Iran partnership might also have to address the spillover effect of religious militancy and instability in Afghanistan, with the US-Taliban peace deal the situation is expected to improve yet the response of other stakeholder excluded from the dialogue still spells uncertainity in the region. China hosts Xinjiang region with $45 \% \mathrm{Muslim}$ population, who have been considered as troubling population factor. However China considers Iran a potential ally in addressing the resurgence of Taliban influence in the adjacent states and their influence in Xinjiang (Zhao, 2014: 411 12). For the development of Xinjiang region China also adopted the mechanism of peace through economic development the same is adopted in Afghanistan and other conflict ridden areas. Yet in the long-run considering Iran a regional power and her influence in Middle East, China would have to consider Iranina policy in the region viz-viz her rivalry with other major powers in the region whom China have more stronger economic and diplomatic ties with. Soft power and public diplomacy is another significant factor of Chinese foreign policy. China-Iran have also expanded cooperation through tourism, cultural and educational exchanges. The cultural cooperation though prevalent since the inception of Silk Road in the ancient times revived after establishing diplomatic relations and both signed agreement for mutual cooperation in cultural, scientific and technical fields. There is a consensus on both sides that 
tourism between the two countries should be enhanced and both states have been cooperation over tourism, they enhanced people-to-people contact through tourism. China also established Confucius institute in Tehran University. The cooperation in tourism further boosted with signing of several agreements during President Xi Jinping's 2016 visit to Iran. For building sustainable and long-term relations the cooperation is extended to other fields including technological, technical, scientific, infrastructural, and small- to heavy-industrial projects, as well as art and cultural undertakings.

\section{Conclusion}

Though the strategic orientation of Iran-China relations is tilted in facor of economic relations, yet with the signing of Strategic Partnership deal these ties would increase Chinese footprints in the region. Both the partner must be prepapred to address the challenges emerging from this growing presence and emerging new security situation. It will be challenging for China to stick to her principle of non-interfernece yet maintain responsible stakeholder status in the region, however China's potential may create space limited security cooperation with the partners in the region. China is adopting a cautious policy towards the region securing her economic and oil interests. Though limited yet influential is the presence of US in the region curtailing China from changing her priorites in the region, however the US deteriorating ties with China and imposing more sanctions against Iran, furvor China's elastic response to Iran. Similarly Iran, in order to reap the benefits of this strategic partnership might have to reconsider her policies towards west and China's other partners in the region. Therefor the partnership will prove to be testcase for both China and Iran, to append and show resilience towards their stated goals and opted policies.

\section{References}

Behbehani, H. (1981) China's Foreign Policy in the Arab World, 1955-75: Three Case Studies. London and Boston: Kegan Paul International.

Calabrese, J. (2006, August 18) China and Iran: Partners Perfectly Mismatched, Manuscript, Washington DC: Middle East Institute.

Daftari, M. (1996, Winter) "Sino-Iranian Relations and 'Encounters' : Past and Present." The Iranian Journal of International Affairs, 7(4), 865-76.

Downs, E. (2006, December) "Energy Security Series: China", Energy Security Series. Washington DC: The Brookings Institution December 2006. Retrieved from http://brookings.edu/fp/research/energy/2006china.pdf on September 30, 2020.

Emadi, H. (1997) China's Foreign Policy Towards the Middle East, Karachi: Royal Book Company.

Fassihi, F \& Myers, S. L. (2020, July 11) "Defying U.S., China and Iran Near Trade and Military Partnership." The New York Times. Retrieved from https://www.nytimes.com/2020/07/11/world/asia/china-iran-trade-militarydeal.html on September 23, 2020.

Financial Tribune, (2015, February 01) “China: Iran's Top Trading Partner." Retrieved from https://financialtribune.com/articles/domestic-economy/10313/china-iran-s-top-tradingpartner?utm_campaign=more-like-this on August 28, 2020.

Financial Tribune, (2017, July 30) "Iran-China H1 Trade Up 31\% to 18 Billion." Retrieved from https:/financialtribune.com/articles/economy-domestic-economy/69312/iran-china-h1-trade-up-31-to-18billion on August 28, 2020.

Full text of Joint Statement on Comprehensive Strategic Partnership between I.R. Iran, P.R. China. (2016, Jan 23) Retrieved from http://www.president.ir/EN/91435 on Aug 21, 2020.

Garver, J. W. (2007) China and Iran: Ancient Partners in a Post-Imperial World, Seattle: University of Washington Press.

Garver, J. W. (2016) "China and Iran: Expanding Cooperation under Conditions of US Domination," in Niv Horesh, ed., Toward Well-oiled Relations? China's Presence in the Middle East Following The Arab Spring, UK: Palgrave Macmillan.

Garver, J. W. (2018) “China and the Iranian Nuclear Negotiations: Beijing's Mediation Effort," in James ReardonAnderson (Ed.), The Red Star \& the Crescent: China and the Middle East. US: Oxford University Press.

Guler, M. A. (2020, September 4) "China and Iran: Obstacles to trade and revised goals for future." Daily Saba. Retrieved from https://www.dailysabah.com/opinion/op-ed/china-and-iran-obstacles-to-trade-and-revisedgoals-for-future on September 23, 2020. 
Hameed, R. (2010, January-June) "Sino-Iran Relations Current Developments and Future Scenario," Policy Perspectives, 7(1), 135-153.

Harold, S., \& Scott, A. (2012) China and Iran: Economic, Political and Military Relations, Santa Monica: RAND Corporation.

Harriosn, R., \& Vatanka, A. (2020, September 19) “China's Plan to Dominate the Middle East Centers Around Iran." The National Interest. Retrieved from https://nationalinterest.org/feature/china\%E2\%80\%99s-plan-dominatemiddle-east-centers-around-iran-169219 on September 26, 2020.

Hounshell, B. (2010, February 9) "China is now Iran's top trading partner," Foreign Policy. Retrieved from https://foreignpolicy.com/2010/02/09/china-is-now-irans-top-trading-partner/ on August 29, 2020.

Hussain, T. (2020, Sep 8). "What is behind the hype about the new Iran-China partnership?" Opinion, Aljazeera. Retrieved from https:/www.aljazeera.com/opinions/2020/9/8/what-is-behind-the-hype-about-the-new-iranchina-partnership/ on Sep 23, 2020.

Jalilov, O. (2020, May 1) “Trade Exchange Between Iran \& China Drops By 30 Percent." Caspian News. Retrieved from https://caspiannews.com/news-detail/trade-exchange-between-iran-china-drops-by-30-percent-2020-4$30-$

45/\#: :text=Iran's\%20exports\%20to\%20China\%20accounted,trade\%20stood\%20at\%20\%241.4\%20billion.\&t ext $=\mathrm{In} \% 202019 \% 2 \mathrm{C} \% 20$ Iran\%2DChina's\%20trade,34.3\%20percent $\% 20$ compared $\% 20$ to $\% 202018$ on September 24, 2020.

Kemenade, W. V. (2009) Iran's Relations with China and the West: Cooperation and Confrontation in Asia, Clingedael Institute.

Khatinoglu, D. (2020, August 27) “China Resumes Reporting Oil Imports From Iran in July.” Radio Farda. Retrieved from https://en.radiofarda.com/a/china-resumes-reporting-oil-imports-from-iran-in-july/30805213.html on September 26, 2020.

Levathes, L. (1994) When China Ruled the Seas: The Treasure Fleet of the Dagon Throne, 1405-1433, New York: Oxford University Press.

Mackenzie, (2010) P. A Closer Look at China-Iran Relations, Roundtable Report, CNA: CNA China Studies.

Payne, J. (2020, September 02) “A China-Iran bilateral deal: Costs all around." The Interpreter. Retrieved from https://www.lowyinstitute.org/the-interpreter/china-iran-bilateral-deal-costs-all-around on September 23, 2020.

Scobell, A. (2018) "China's search for security in the Greater Middle East," in James Reardon-Anderson (Ed.), The Red Star \& the Crescent: China and the Middle East. US: Oxford University Press.

Yacoubian, A . (2019, September 11) "Iran's Increasing Reliance on China." The Iran Primer. Retrieved from https://iranprimer.usip.org/blog/2019/sep/11/irans-increasing-reliance-china on August 28, 2020.

Zhao, H. "China's Dilemma on Iran: between energy security and a responsible rising power." Journal of Contemporary China,23(87),408-424. 